\title{
Forecasting the Number of Foreign Tourist Visits in Sabang in the Next Five Years
}

\author{
Herlina $^{1}$, Muhammad $^{2}$ \\ \{1herlina.smanap@gmail.com\} \\ ${ }^{1}$ Lecturer at the Faculty of Economics and Education, Universitas Serambi Mekkah \\ ${ }^{2}$ Lecturer at Chemical Engineering, Universitas Serambi Mekkah
}

\begin{abstract}
This study aim to forecast foreign tourist visits in Sabang. The study utilized the secondary data obtained from the Sabang Culture and Tourism Office and Aceh Province. Data was analyzed by using Excel program, because the data was only five years. The results of the study show a trend estimate: $\mathrm{Y}=117060 \mathrm{x}+216768$. The $\mathrm{R}^{2}$ value is 0.9879 which is an appropriate or appropriate model. With the increasing number of tourists, the effort to search for development strategies always needs to be carried out continuously. Furthermore, the data can be reproduced with an additional five years before the forecast starts.
\end{abstract}

Keywords: Forecasting, Foreign Tourists, The Number of Tourists.

\section{Introduction}

\subsection{Background}

\subsubsection{Sabang Vision and Mission}

Based on the vision, mission and strategic environmental review, Sabang's long-term development goals for 2007-2027 are to realize the advanced, prosperous, faithful, and good and authoritative Sabang City. To realize the long-term development goals of Sabang City within the next 20 years, the stages are carried out according to the medium-term plan period (5 years), namely 4 stages in accordance with the development of conditions, resource capabilities and priority scale. The policy of each stage is made sustainable so as to achieve the development vision of Sabang City in the next 20 years. The following are the main policy objectives outlined in the RPJP stages.

Each stage of RPJP (I: 2007-2012, II: 2012-2017, III: 2017-2022, IV: 2022-2027), consists of Economic Development, Development of Facilities and Infrastructure, Development of Education, Health Development, Development of Public Governance, Development Religion and Social Culture:

Phase 1 (2007-2012) in terms of economic development, the policy objectives to be achieved are:

a. Increasing the welfare of the community and the reduction of the poor through facilitation of basic needs, empowerment of business groups and communities, proportional and modern coaching of the informal sector business.

b. The realization of food security through efforts to intensify agricultural businesses, especially food crops and horticulture, and improvement of fishery products. 
c. The increase in the number of tourist visits to the City of Sabang so as to increase tourism business community.

d. The establishment of the main facility of Sabang Free Port Area as the main port (hub port) which functions as a port of import-export (international) and also as a port of national transhipment in accordance with the mandate of Law Number 37 of 2000 and Law Number 11 of 2006.

e. Port and trade activities are running even though it is still a small scale.

f. The establishment of People's and Modern Fisheries Ports as an effort to realize export activities through the Sabang Free Trade Area.

g. Availability of sufficient energy energy resources that support investment.

Phase 2 (2012-2017) in terms of economic development, the policy objectives to be achieved are:

a. Increased development of the main facilities of the Sabang Free Port Area as the main port (hub port) whose function is as an international (import) port of import and also as a national port for transhipment, in accordance with Law Number 37/2000 and Law Number $11 / 2006$.

b. The running of trade activities and export / re-export activities of domestic / foreign commodities through Sabang Free Port.

c. Increased public welfare through the activities of SMEs, small industries and trade in industrial products of the people of Sabang City.

d. Maintaining food security through intensification of agricultural, maritime and fisheries businesses so as to reduce dependence on staple foods from outside the city of Sabang.

e. Increasing the number of tourist visits to the City of Sabang so that the tourism business of the community and the tourism industry increases.

f. The functioning of people's and modern fishing ports as an effort to realize export activities through the Sabang Free Trade Area.

g. Increase the adequacy of electrical energy resources that support investment by striving to utilize Jaboi geothermal energy sources.

The third stage (2017-2022), the economic development goals through the policies to be achieved are:

a. Increasing the completeness of the main facilities and infrastructure and supporting the Sabang Free Port Area as the main port that functions as an international (import) port of import and also as a national port for transhipment.

b. Increased port and trade activities and national export / re-export-import and transhipment activities.

c. Increased welfare of the community through small industry activities and trade in community industrial products and development of leading sectors in the City of Sabang.

d. Stable community agricultural production in maintaining food security as an effort to maintain regional independence.

e. The number of tourist visits has increased very significantly to the City of Sabang so that it has an impact not only on the community of tourism actors but also on the wider community.

f. Increased export activities of fishery products and increased welfare of fishing communities.

g. Guaranteed availability of electrical energy resources that support investment by utilizing Jaboi alternative geothermal energy sources.

Finally, at stage 4 (2022-2027) in terms of economic development, the policy objectives to be achieved are:

a. The realization of the completeness of the main facilities and infrastructure and the support of the Sabang Free Port Area as the main port that functions as a port of import-export (international) and also as a port for the transfer of national transhipment. 
b. The development of trade / commerce in the city of Sabang which is the center of the Sabang Free Port and Free Trade Zone, both at the regional level (Aceh's export-import gate), nationally and internationally.

c. The development of the tourism sector, with the characteristics of the typical region and quality infrastructure and facilities make Sabang as the main tourist destination in Aceh and is well-known nationally and internationally with the mainstay of marine tourism, cultural/historical/heritage attractions and natural tourism, which has an impact on increasing economic activity the community.

d. The development of the fishing industry accompanied by increased fisheries production is the mainstay of Sabang's export commodity.

e. Development of Balohan Industrial Area (KIB) for the development of mechanical / automotive industries, and other industries that are of high quality and competitive.

f. The development of small and medium enterprises and cooperatives as a result of the development of the free trade area and free port of Sabang.

$\mathrm{g}$. The realization of the availability of sufficient energy resources to meet the basic needs of the community and support investment.

h. Achieving quality and sustainable economic growth so that per capita income in 2027 reaches a level of prosperity and a small poverty rate.

\subsubsection{Sabang Tourism Potential}

Sabang's vision and mission are in line with its potential as a tourist city with marine tourism types divided by sub-districts as follows:

a. Sukakarya District: Iboih tourism forest, Rubiah marine park, Gapang Island, Teupin Layee Island, Teupin Sirkui Beach, Lueng Angin Beach, Kasih Beach, Pria Laot Beach, Aneuk Laot Lake, Km Nol Monument, Sarang Cave, Swimbath, Paradiso Beach, water plunge

b. Sukajaya District: Pasir Putih Beach, Keunuekai Hot Beach, Tapak Gajah Beach, Aroun Beach, Sumur Tiga Beach, Reuteuk Beach, Jaboi Hot Springs, Balohan Beach, Chum Beach.

The Director General of Destination Development at the Ministry of Tourism and Creative Economy has set Sabang as Indonesia's Leading Nature Destination along with 44 other tourist objects / regions. Welcoming the Asean Economic Community the readiness of all sectors that are expected to rapidly develop rapidly is education and tourism, because in Indonesia these two sectors are considered to be relatively more ready to compete compared to other sectors.

The development of tourists in Sabang will affect the economies of other regions in Aceh Province such as Banda Aceh and Jantho, because tourism is an industrial sector that will attract other sectors to develop as well. To make a tourist development strategy in Sabang, forecasting the number of foreign tourists to Sabang in the next five years is important.

\subsection{Formulation of the Problem}

Based on the background picture, the formulation of the problem of this research is how to forecast the number of foreign tourist visits in the next five years?

\subsection{Research Purposes}

The purpose of this study was to determine the forecasting number of foreign tourist visits in the next five years.

\subsection{Scope of Problem}

This study uses data on the number of foreign tourist arrivals in 2013-2017 in Sabang. 


\subsection{Benefits of Research}

With the forecast of foreign tourists, it is hoped that the Sabang City government will always pay attention and develop their potential. In addition, it can be a reinforcement so that service is improved.

\section{Methodology}

\subsection{Populatioan and Research Sample}

The population in this study was the number of tourist visits in Sabang, while the research sample was in 2013-2017. This study uses secondary data obtained from the Sabang Culture and Tourism Office and Aceh Province, and through related agency reports, related literature studies, and documentation.

\subsection{Research Instrument and Data Collection Techniques}

Data collection at the Culture and Tourism Office (DISBUDPAR) of Sabang and Aceh can be seen in Table 1.

Tabel 1.Research Data Collection Methods and Instruments

\begin{tabular}{lllll}
\hline Data Type & \multicolumn{2}{c}{ Data Retrieval } & Data Collection Technique & \multicolumn{1}{c}{$\begin{array}{c}\text { Research } \\
\text { Instrumen }\end{array}$} \\
\hline Secondary & $\begin{array}{l}\text { Number of foreign tourist } \\
\text { visits over the past five years }\end{array}$ & $\begin{array}{l}\text { Dinas Kebudayaan dan } \\
\text { Pariwisata } \\
\text { Sabang and Aceh }\end{array}$ & $\begin{array}{l}\text { Documentation } \\
\text { (DISBUDPAR) }\end{array}$ & \\
\hline
\end{tabular}

\subsection{Processing and Analysis of Data}

Data processing to project tourism growth in the next five years is obtained through an excell program. While the data analysis is done descriptively and to simplify the explanation, a statistical table is used.

\section{Results And Discussion}

\subsection{Tourism Devisa}

In 2018, the tourism sector is predicted to become Indonesia's largest foreign exchange contributor of US $\$ 20$ billion, an increase of around 20 percent from 2017, which is around US \$ 16.8 billion. The highest QPI (quality performance index) tourism is to bring in foreign tourists or generate foreign exchange. The contribution of tourism foreign exchange to other exorced commodities can be seen in Table 2 . 
Table 2. Tourism Foreign Exchange Ranking of Other Export Commodities2011-2015

\begin{tabular}{|c|c|c|c|c|c|c|c|c|c|c|}
\hline \multirow[b]{2}{*}{ lank } & \multicolumn{2}{|l|}{2011} & \multicolumn{2}{|l|}{2012} & \multicolumn{2}{|l|}{2013} & \multicolumn{2}{|l|}{204} & \multicolumn{2}{|l|}{2015} \\
\hline & lexis Komodtas & $\begin{array}{c}\text { Nial } \\
\text { Gutus usor }\end{array}$ & lentra Konodilis & $\begin{array}{c}\text { Noloi } \\
\text { [ut U USO] }\end{array}$ & Jents komodtas & $\begin{array}{l}\text { Whial } \\
\text { (Wisu uso) }\end{array}$ & Jeniskomodtus & $\begin{array}{l}\text { Noisi } \\
\text { (utauso) }\end{array}$ & Jens Komodtas & 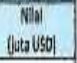 \\
\hline & & & & & & & & & & \\
\hline 1. & 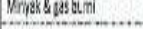 & $(1, A 7), 10$ & 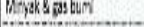 & $3(69972.03$ & Morald gas bum & 32,63320 & 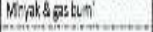 & $36,319,894$ & Mngkelapsbami & 18,5210 \\
\hline 2 & Antwbrn & 27211180 & Etaban & $26,153: 30$ & Jas bar & 2450140 & Batshar & 20,81935 & Batubara & 15,4480 \\
\hline 3 & Nrpakkelipsswit & 27,26130 & Mratkenipesawt & 188.5600 & Vryakkelipa sait & 1589010 & Wonyeketsosswit & $17,660: 90$ & 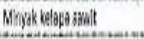 & $15 ; 3520$ \\
\hline 4 & (anodinn & 2425820 & Sareolonn & 10)30150 & Pariviats & IQQPS4, 13 & Porivigate & 11,10018 & Pectwisto & $12,25,89$ \\
\hline \& & Porilifies & 8554, s: & Portivisato & Q122085 & Gret oblan & 91660 & Alaben ad & 3,55990 & Pakian jad'. & 7,87280 \\
\hline 6 & Perescist & 700.50 & Pikghngel & 73070 & Pesain ad at & 1,0000 & krat dasn & 702170 & Mekarsn disinn & 6,45620 \\
\hline ? & Alatlitsik. & 74430 & Matlltstik & 648190 & Aletilistik & 644866 & Mabrendatan & 605550 & Karcodohn & 504200 \\
\hline 1 & Tekstl & $5,663.30$ & Terstl & $\$ 272: 10$ & Maknar odatan & $5,434.89$ & Anllatili & $6 ; 59: 0$ & Aat isti & 564.80 \\
\hline 1 & Mararan clathan & 4,80210 & Maknun cathan & $5,356,66$ & Tnktti & 5,23960 & Toksti & 8,37970 & Thesl & $4,9960.00$ \\
\hline 10 & Bitanking & 4,63000 & Kents con lirand d kentes & 392.66 & 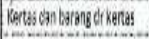 & $3,622.20$ & Kays olsits & 198110 & Rewe catlan & $3,815,800$ \\
\hline 4. & 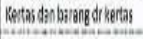 & 422440 & Ben: kim & 36630 & Kaw oksian & 9,51450 & What kimiti & 835870 & Kertas den berreg of ketts & $3,655,50$ \\
\hline 12 & kawdathan & 2,4850 & Rave othan & $3,337.70$ & Bannimim: & $3,50.60$ & Kertas dan baereng de luertse & 3,60000 & Batankmals & 2807.60 \\
\hline
\end{tabular}

Source: www.kemenpar.go.id

Table 2. shows that in 2011 tourism contribution compared to other export commodities was at number V, and since 2013-2015 it has increased to IV.

\subsection{Origin of Foreign Tourist}

As long as foreign tourists according to Disbudpar in 2017, can be seen in Graph 1.

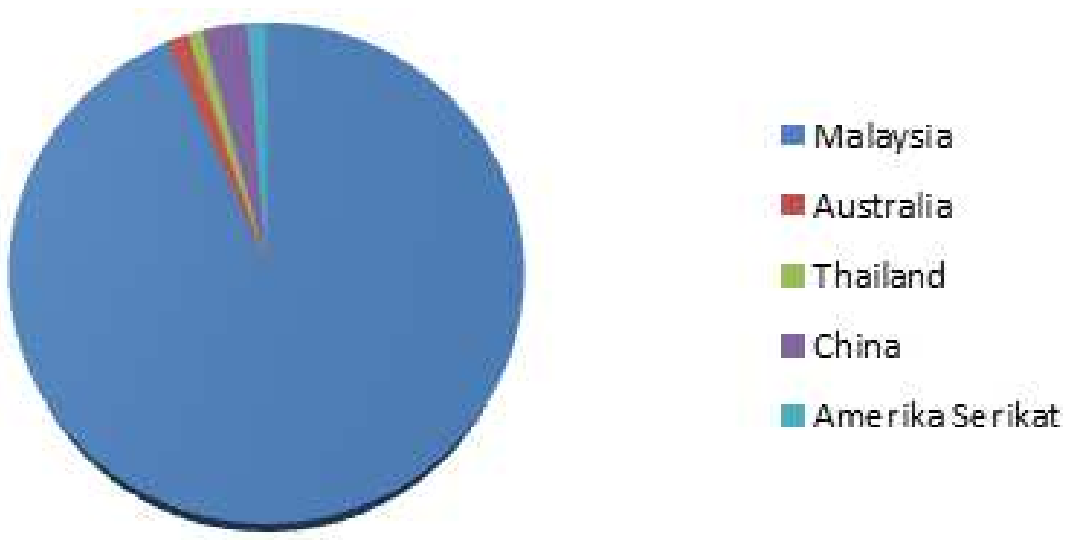

Source: Disbudpar, 2018

Graph 1. Visit of Foreign Touristsaccording to Nationality in 2017

Graph 1. shows that the highest number of foreign tourists visiting Aceh Province is Malaysia as many as 24,748 people, while the lowest is Thailand as many as 267 people. Malaysia is a major market for halal tourism. 


\subsection{Sabang Foreign Tourist Forecast}

The number of foreign tourist visits in the last 5 years can be seen in Table 3 .

Table3.Number of Foreign Tourist Visits to Sabang 2013-2017

\begin{tabular}{cccccc}
\hline Tourist Type & \multicolumn{5}{c}{ Year } \\
\cline { 2 - 6 } & $\mathbf{2 0 1 3}$ & $\mathbf{2 0 1 4}$ & $\mathbf{2 0 1 5}$ & $\mathbf{2 0 1 6}$ & $\mathbf{2 0 1 7}$ \\
\hline Foreign Tourists & 4,648 & 3,492 & 5,582 & 10,038 & 6,031 \\
\hline
\end{tabular}

Source: Dinas Kebudayaan dan Pariwisata Sabang, 2018.

Table 3 shows that over the past five years the number of foreign tourist arrivals has increased on average. From these data we can forecast the number of tourist visits for the next five years which can be seen in Graph 2.

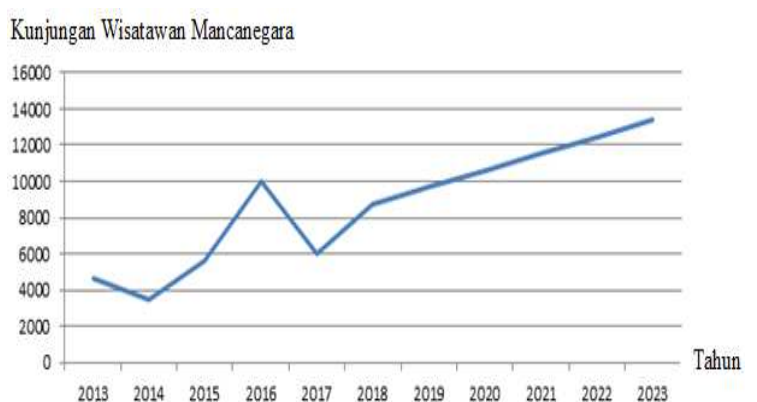

Graph2.Forecast Number of Foreign Tourist Visits to Sabang Source: secondary data, processed, 2018.

Graph 2. shows the trend in the number of foreign tourist arrivals over the next five years starting from 2018-2023 has increased. This trend shows:

$\mathrm{Y}=117060 \mathrm{x}+216768$, dengan $\mathrm{R}^{2}=0,9879$

The $\mathrm{R}^{2}$ value indicates that the forecasting model fits 98 percent.Forecasting the number of foreign tourist arrivals in Sabang has increased in 2018-2022, as well as [1] in Lombok in 2010-2015, where the number of tourist visits has increased.

Table4. Visiting Forecast Results Foreign Tourists to Sabang

\begin{tabular}{cc}
\hline Year & Forecast (people/thousands) \\
\hline 2018 & 5940 \\
\hline 2019 & 6286 \\
\hline 2020 & 6898 \\
\hline 2021 & 7074 \\
\hline 2022 & 6289 \\
\hline
\end{tabular}

Source: secondary data, processed, 2018.

Table 4. shows that there has been an increase in the number of foreign tourist arrivals on average over the next five years since 2018. The Government of Aceh's target in 2018 is to increase the number of foreign tourists to Aceh Province by 100 thousand, meaning the forecasting result of 5940 people has been exceeding the target. 


\section{Conclusion}

Conclusions from the results of this study show the results of the forecast of foreign tourists shows an increase in the number of tourist visits for the next five years.

\section{References}

[1] S. R. Ainy, "Peramalan Kunjungan Wisatawan Mmancanegara di Kabupaten Lombok Tengah pada Tahun 2010-2015 Menggunakan Metode Sarima (Seasonal Autoregressive Integrated Moving Average)," 4th Call Syariah Pap. ISSN 2460-0784. P 396-408, 2016.

[2] Dinas Kebudayaan dan Pariwisata Provinsi Aceh. 2018. Jumlah Kunjungan Wisatawan Mancanegara ke Sabang.

[3] ------- Lima BesarKunjungan Wisatawan Mancanegara ke Acehmenurut Kebangsaan Tahun 2017.

[4] Qanun kota sabang nomor 4 tahun 2009 mengenai Rencana Pembangunan Jangka Panjang Daerah (RPJPD) Kota Sabang Tahun 2007-2027.

[5] www.kemenpar.go.id.Rangking Devisa Pariwisata terhadap Komoditas Ekspor Lainnya. Diakses pada 1 Oktober 2018. 